\title{
Sustainability of capture of fish bycatch in the prawn trawling in northeastern Brazil
}

\author{
Carlos Antônio Beserra da Silva Júnior ${ }^{1}$, Maria Elisabeth de Araújo ${ }^{2}$ and \\ Caroline Vieira Feitosa ${ }^{3}$
}

\begin{abstract}
The prawn fishery produces more discards than any other type of catch and captures a large quantity of immature individuals. This research aimed to assess the sustainability of capture of fish bycatch in prawn trawling. Each species was assessed according to two groups of criteria: (1) their relative vulnerability to capture by trawl and mortality due to this fishery (2) recovery capacity of the specie after a possible collapse of the population. Within each group, each species was ranked (1-3), being 1 the highest value, meaning the species is highly susceptible to capture or has a low resilience. A total of 8,894 individuals were caught, belonging to 28 families. The species with capture least sustainable were Stellifer rastrifer and Isopisthus parvipinnis. These latter species are highly susceptible since they are either benthic or demersal, and their diet may include benthic organism. Chirocentrodon bleekerianus and Anchoa tricolor were the most likely fishes to be sustainable since they are pelagic, they are least susceptible to capture by trawls, and also have a greater capacity to recover, as most individuals have bred before capture. Due to the fishery's multi-specific nature, it is difficult to implement mitigation measures for specific species. Thus, the creation of fishing exclusion zones should be considered as the most appropriate management measure.
\end{abstract}

A pesca de arrasto de camarão produz mais descarte do que qualquer outra pescaria e captura uma grande quantidade de indivíduos imaturos. Esta pesquisa visa determinar a sustentabilidade da captura da ictiofauna acompanhante na pesca de arrasto de camarão. Cada espécie foi analisada de acordo com dois grupos de critérios: (1) vulnerabilidade à captura pela rede de arrasto e mortalidade ocasionada por esta pescaria; e (2) capacidade de recuperação da população para minimizar. Dentro de cada critério as espécies foram classificadas de 1 a 3, sendo 1 o valor mais alto, indicando que a espécie é altamente susceptível à captura ou tem baixa capacidade de recuperação. Um total de 8.894 indivíduos foram capturados, pertencendo a 28 famílias. As espécies com captura menos sustentável foram Stellifer rastrifer e Isopisthus parvipinnis. Estas espécies são altamente susceptíveis, pois são bentônicas ou demersais e suas dietas incluem organismos bentônicos. Chirocentrodon bleekerianus e Anchoa tricolor foram as espécies que apresentaram a captura mais sustentável. Por serem pelágicas, são menos susceptíveis à captura por arrastos de fundo, além disto, apresentaram uma grande capacidade de recuperação, pois a maior parte dos indivíduos capturados encontrava-se acima do seu tamanho de primeira maturação sexual. Devido à natureza multiespecífica da pescaria é difícil implementar medidas mitigatórias específicas. Assim, a criação de zona de exclusão de pesca deve ser considerada como a medida de manejo mais adequada.

Key words: Demersal fish, Recovery, Sandy beach, Susceptibility, Vulnerability.

\section{Introduction}

Due to the technological advances and the increase in the number of fishing fleets, fish stocks are undergoing intense pressure and, consequently, overexploitation (Isaac et al., 2006). Prawn trawling has become quite prominent in recent years - it is practiced along almost the entire Brazilian coast and promotes economic and social development in the regions where it is carried out (Branco, 2005). However, this kind of fishery is extremely heterogeneous as a result of the low selectivity of the fishing gear used (Klippel et al., 2005).

As a result of the use of trawls, prawn fishing is a major threat to marine environments. Among the main consequences of this fishery are direct and indirect impacts

${ }^{1}$ Universidade Federal Rural de Pernambuco, Programa de Pós-Graduação em Recursos Pesqueiros e Aquicultura, Departamento de Pesca e Aquicultura. Rua Dom Manoel de Medeiros, s/n, Dois Irmãos, 52171-900 Recife, Pernambuco, Brazil. carlos_junior92@hotmail.com ${ }^{2}$ Universidade Federal de Pernambuco, Departamento de Oceanografia, Centro de Tecnologia e Geociências. 50670-901 Recife, Pernambuco, Brazil.elisabeth.araujo@ufpe.br

${ }^{1}$ Universidade Federal Rural do Semiárido, Departamento de Ciências Animais. Avenida Francisco Mota, 59625-900 Mossoró, Rio Grande do Norte, Brazil. caroline@ufersa.edu.br 
on ecosystems and biodiversity (Kinieb, 1991), physical alterations in the seabed (e.g., due to the removal of rocks and corals and the flattening of the bottom's natural topography) (Pilskaln et al., 1998) and changes in chemical cycles, carbon mineralization patterns and biogeochemical flows (Riemann \& Hoffman, 1991).

The prawn fishery produces more discards than any other type of catch, and it is the source of more than one-third of the world's total bycatch (Alverson et al., 1994). The total amount of discards is approximately five times the production of prawn, and it is one of the major problems related to the use of marine resources (Clucas, 1997). Another important characteristic of this activity is the capture of immature individuals (Branco, 1999; Branco \& Verani, 2006).

A significant part of the fauna caught in trawl fisheries is returned to the sea either because it has no economic importance or they are small (even if they are target species). Large quantities of individuals are returned to the sea dead and for this reason are called discard or reject (Branco, 1999). Bycatch is the portion of the catch that is returned to the sea for economic, legal or personal decisions along with the nontarget species captured from fishing (McCaughran, 1992).

Although fish constitutes the main component of incidental capture, many species are often captured but they are not quantified in the fishing statistics (Coelho et al., 1986). The bycatch composition consists mainly by juvenile individuals which represent a considerable loss for future food biomass and can potentially affect the sustainability of fish stocks (Tischer \& Santos, 2001).

Little is known about the life cycle of the bycatch species. Furthermore, many individuals are often caught before reaching the size of first sexual maturity (Pina \& Chaves, 2009). Research on prawn fishery bycatch has been limited to recording and quantifying species (Vianna \& Almeida, 2005). Only two studies have been focused on the sustainability of the bycatch (Stobutzki et al., 2001; Feitosa et al., 2008), but only Stobutzki et al. (2001) evaluated the impacts of a prawn fishery.

A population can vary in size length throughout time and is directly connected to fertility stages and to the environment, the latter which can make species undergo changes from one year to another (Nikolskii, 1969). Such information makes it possible to conduct studies to determine the equilibrium of a given population.

In this context, the aim of this research was to assess the bycatch fish species' resilience and susceptibility to trawls and verify their susceptibility and resilience as bycatch within a prawn fishery in northeastern Brazil.

\section{Material and Methods}

Study Area. São Cristóvão Beach, the study area, is located

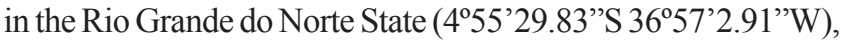
northeastern Brazil. This beach is located in a shallow bay (Fig.1) and the bottom is sandy/muddy. This region is characterized by a semi-arid climate with prevailing hot/dry

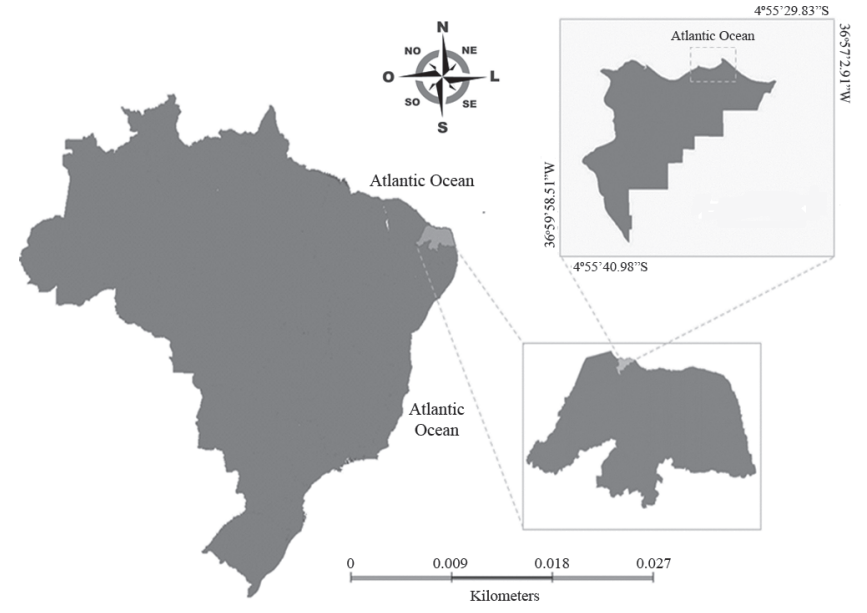

Fig. 1. Map of northwestern Brazil showing location of study area in São Cristóvão beach.

(June to January) and rainy seasons (February to May); the average annual precipitation is less than $750 \mathrm{~mm}$ (Idema, 2002, 2003). The tide follows a semidiurnal pattern that displays a daily disparity; the average sea level is of $133.1 \mathrm{~cm}$ and the quadrature and spring tidal range is of $127.79 \mathrm{~cm}$ and 284.55 $\mathrm{cm}$, respectively (Garcia Júnior, 2006). Northeast-east winds stand out in this region, with higher speeds in the summer; a maximum of $8.5 \mathrm{~m} / \mathrm{s}$ is reached in October and a minimum of $0.7 \mathrm{~m} / \mathrm{s}$ during the winter month of April (Idema, 2003).

Sampling. Sampling was carried out monthly from February 2010 through January 2011, during spring tide, in shallow areas $(6 \mathrm{~m})$, parallel to the shoreline and in direction of the current for 30 minutes. A $15 \mathrm{~m}$ long and $8.60 \mathrm{~m}$ wide bottom trawl, with a 4 $\mathrm{cm}$ opening, was pulled by a prawn boat with a 46-HP 6-cylinder engine at a speed of 2.5 knots. Fish collected were kept in a Styrofoam box and then brought to the laboratory, where they were stored in a freezer and later identified, weighed and measured (total length). The samples are deposited at the Biologia e Dinâmica Populacional de Peixes Marinhos Laboratory Collection under the numbers 1-50.

Data Analysis. Fish species were analyzed according to biological and ecological characteristics (Figueiredo \& Menezes, 1978, 1980, 2000; Menezes \& Figueiredo, 1980, 1985; Carvalho Filho, 1999; Froese \& Pauly, 2011). Only those species with abundances greater than $0.5 \%$ of the total number of fishes were analyzed. The method proposed by Stobutzki et al. (2001) and adapted by Feitosa et al. (2008) was modified and used to assess the sustainability of fish bycatch in a prawn fishery.

Two sustainability criteria were used: (1) vulnerability to capture and mortality by trawling, and (2) the species' resilience after potential population collapse. Values ranging from 1 to 3 were assigned for each sustainability index, where one means the species is highly susceptible to capture and/ or has a low capacity to recovery (Table 1). The values obtained 
for each group of criteria were plotted on a graph that indicated the species which capture was more or less sustainable. When specific information about a certain species was not available, the same value given to the other species of the family or genus was attributed. If the information for species or genus of this family was not available, the value 1 was assigned as a precautionary approach (Stobutzki et al., 2001).

The day/night catchability proposed by Stobutzki et al. (2001) was not considered in this study due to the scarcity of the target species (prawns). As a result, nowadays the prawn fishery occurs for 24 hours (Tomáz et al., 2003).

It was observed that the species analyzed in this research showed a preference for the same type of habitat. Thus, this criterion did not directly interfere in the analysis. A similar situation was observed for the depth criterion. Since trawling was always conducted in depths $<40 \mathrm{~m}$, this did not influence species' capture and was therefore removed from the analysis. As all captured taxa were dioecious, therefore hermaphroditism did not interfere directly in the analysis of species recoverability and was therefore ignored.

The criteria used to analyze species' susceptibility to capture and to mortality associated with trawling were applied as follows: a) Water-column position: as the prawn trawls are usually operated near the bottom, benthic and demersal species are more likely to be captured than pelagic ones (Stobutzki et al., 2001). b) Survival: this criterion was described in a study by Wassenberg \& Hill (1989) and Hill \& Wassenberg (1990) on the survival of bycatch caught in trawls. After being trawled, individuals were observed and the researchers recorded whether they were alive or dead. Survival was divided into three categories, based on species frequency: survival probability $\leq 33.3 \% ; 33.3<$ survival probability $<66.6 \%$; and survival probability $\geq 66.6 \%$. c) Diet: this criterion is related to the occurrence of species' main food items in the areas where trawling occurs. Species that feed on benthic and/or demersal organisms have a greater susceptibility to trawling than those that feed on pelagic organisms.

Five criteria were analyzed to evaluate population resilience: 1) maturity, 2) maximum size, 3) relationship between yield and fishing effort (catch per unit effort - CPUE), 4) reproductive strategy and 5) mortality.

Maturity is related to the probability that most individuals be captured after reaching the size of first maturity established for certain species (Stobutzki et al., 2001). If the fishery has been capturing individuals larger than the size of first maturity, respective populations will have a greater possibility to recover in case of decline (Robert $\&$ Hawkins, 1999). Maximum size was used as a relative indicator of its resilience. Large sized species tend to live longer, grow slowly and mature late; thus, their populations recover at a slower pace than those that grow to smaller sizes (Robert \& Hawkins, 1999). Relationship between yield and fishing effort: the catch per unit effort (CPUE) is usually not proportional to the abundance of the resource or species (Jennings et al., 2001). However, if a certain species has little ability to recover and is removed from the environment in large quantities, it can be susceptible to becoming at risk of extinction (Fonteles-Filho, 1989). In this study all valor analyzed were distributed in three ranges to facilitate the classification between the weights (1,2 and 3) used herein (Table 1). The unit used for this criterion was individuals/hours of trawling. Reproductive strategy: species able to disperse for long distances are less vulnerable to a possible risk of extinction (Robert \& Hawkins, 1999). Thus, the resilience of $r$-strategist species is greater than that of k-strategist species. Mortality refers to the resilience of a given population directly related to the mortality index (Sparre \& Venema, 1997). Mortality was calculated using the following formula: Mortality index = (Lmax - Lmed)/(Lmed - Lmin), where: Lmax - maximum length reported in the literature; Lmed - average total length of individuals captured; Lmin - minimum length of individuals observed in the sample. Considering the minimum and maximum values found for the 17 species analyzed, three mortality index classes were determined; this corresponds to the 1-3 weights, as indicated in Table 1.

In order to calculate the rates of susceptibility or total removal,

Table 1. Criteria used to assess susceptibility of bycatch species to capture and mortality due the trawling. For each criterion, the weighting score and definition was established on the tree ranks.

\begin{tabular}{|c|c|c|c|c|}
\hline Criteria & $\begin{array}{l}\text { Weighting } \\
\text { score }\end{array}$ & 1 & 2 & 3 \\
\hline \multicolumn{5}{|l|}{ Susceptibility } \\
\hline $\begin{array}{l}\text { Water column } \\
\text { position }\end{array}$ & 3 & Demersal or benthic & Benthopelagic & Pelagic \\
\hline Survival & 3 & Survival probability $\leq 33.3 \%$ & $33.3 \%<$ survival probability $\leq 66.6 \%$ & Survival probability $>66.6 \%$ \\
\hline Diet & 3 & $\begin{array}{c}\text { Feed on demersal or benthopelagic } \\
\text { organisms }\end{array}$ & Feed on benthopelagic organisms & Feed on pelagic organisms \\
\hline \multicolumn{5}{|l|}{ Resilience } \\
\hline Maturity & 3 & Mature individuals $<50 \%$ & - & Mature individuals > $>50 \%$ \\
\hline Maximum size & 3 & Maximum size $\geq 33.8 \mathrm{~cm}$ & $10.6 \mathrm{~cm}<$ maximum size $<33.8 \mathrm{~cm}$ & Maximum size $\leq 10.6$ \\
\hline CPUE & 3 & $\begin{array}{c}\text { CPUE } \geq 42.7 \text { individuals/hours of } \\
\text { trawling }\end{array}$ & $\begin{array}{c}1.4 \mathrm{inds} / \mathrm{h} \text { of trawling }<\text { CPUE }<42.7 \\
\text { inds/hours of trawling }\end{array}$ & $\begin{array}{c}\text { CPUE } \leq 1.4 \text { inds/hours of } \\
\text { trawling }\end{array}$ \\
\hline Reproductive strategy & 2 & Viviparous & Demersal spawning/Parental care & Pelagic spawning \\
\hline Mortality index (Z) & 1 & Mortality index $\geq 17.9$ & $0.67<$ Mortality index $<17.9$ & Mortality index $\leq 0.67$ \\
\hline
\end{tabular}




$$
S i=\sum_{j=1}^{n}(w j . R i) / \sum_{j=1}^{n} w j
$$

the following equation was used (Stobutzki et al., 2001):

where, Si refers to the ranking of total susceptibility or recovery of species $I, w j=$ weight of criterion $j$, and $R i=$ weight of species I for criterion $\mathrm{j}$, and $\mathrm{n}=$ total number of criteria for each axis.

Statistical analysis. The data were log-transformed $(\ln (\mathrm{TL}))$ and the Liliefors test was used to evaluate data normality (BioStat 5.0 software - Instituto de Desenvolvimento Sustentável Mamirauá). Parametric tests and multivariate analysis were also used. The $\mathrm{Z}$ test (BioStat 5.0 software) was applied to check the probability of fish being caught before or after reaching the size at first maturity, while the factorial correspondence analysis (FCA) (Multivariate Statistical Package - MVSP 3.1 software) was used to determine and describe the correlation between species and each criterion evaluated. The significance level applied was 0.05 .

\section{Results}

A total of 8,894 individuals were caught as bycatch, which belonged to 58 species, 48 genera, and 28 families (Table 2). This study shows that prawn trawling is not selective, as most of the individuals caught were imature. They belong to the following families: Sciaenidae (5 spp), Haemulidae (2 spp), Pristigasteridae (2 spp), Ariidae (2 spp), Engraulidade (3 spp), Carangidae (2 spp) and Polynemidae (1 spp). Pomadasys corvinaeformis (Steindachner, 1868), Cathrops spixii (Agassiz, 1829), Stellifer rastrifer (Jordan, 1889) and Pellona harroweri (Fowler, 1917) represented more than $50 \%$ of the individuals captured. All species identified as frequent were abundant in catches, with the exception of Isopisthus parvipinnis (Cuvier, 1830) and Anchoa tricolor (Spix and Agassiz, 1829), which were present in less than half of the sampling months (Table 2).

The information provided by the susceptibility criterion was specific to each species. The values obtained for this criterion ranged from 1.0 to 1.7. Polydactylus virginicus (Linnaeus, 1758) and Chirocentrodon bleekerianus (Poey, 1867) showed the lowest and highest values for susceptibility, respectively. Thus, it can be stated that $P$. virginicus, followed by Menticirrhus americanus (Linnaeus, 1758), $P$. corvinaeformis, S. rastrifer and I. parvipinnis showed great susceptibility to the fishing gear used, while C. bleekerianus, Larimus breviceps Cuvier, 1830, Conodon nobilis (Linnaeus, 1758), Anchoa spinifer (Valenciennes, 1848), Cetengraulis edentulus (Cuvier, 1829) and A. tricolor were the least susceptible to the trawl (Fig. 2). Bagre marinus (Mitchill, 1815) and A. tricolor had the highest $(Z=17.9)$ and lowest $(Z=0.7)$ values for the mortality index, respectively (Table 3 ).

Concerning the ability to recover, S. rastrifer and $I$. parvipinnis had the lowest values, although $A$. tricolor, $C$. bleekerianus, P. harroweri, Stellifer stellifer (Bloch, 1790), and Selene vomer (Linnaeus, 1758) presented the greatest resilience (Fig. 2). The mean and minimum lengths recorded for S. rastrifer and I. parvipinnis were below their size at first maturity. The probability that individuals of these species be caught before having bred for the first time is of $38.5 \%$ and $45.6 \%$ for $S$. rastrifer and I. parvipinnis, respectively. The opposite was observed for C. spixii, S. stellifer and C. bleekerianus, with probabilities of $85.1 \%, 98.8 \%$ and $94.4 \%$, respectively (Table 3). Based on all these information's, it can be said that the species with capture most likely to be sustainable are C. bleekerianus and A. tricolor, while $S$. rastrifer and I. parvipinnis are the least likely.

The correspondence analysis for resilience and susceptibility showed that P. harroweri, C. bleekerianus, A. tricolor, S. stellifer and $C$. spixii were associated with the maturity criterion. In relation to survival, this criterion had a positive influence on $C$. spixii and B. marinus (Fig.3). Diet and position in the water column were essential to the low susceptibility of $C$. edentulus and $A$. spinifer to the fishing gear. Negative relationships were observed for $C$. spixii and B. marinus with diet and position in the water column criterion; $C$. edentulus, $P$. harroweri, $C$. bleekerianus, A. tricolor and $A$. spinifer with the survival criterion; B. marinus, P. corvinaeformis, and $M$. americanus with maturity (Fig.3). The cumulative percentage of variation for the two axes was of $89.39 \%$.

\section{Discussion}

The methodology used in this study was applied to classify bycatch fish species according to potential risk of extinction as a result of the incidental capture. Such an analysis is influenced by fish length, the proportion of young and immature individuals, fish maximum length, size at first maturity, and mortality rate. All species analyzed were susceptible to trawling in different levels.

The results presented showed that benthopelagic and demersal or benthic species were more vulnerable to the prawn fishery's gear; it catches mainly species with this pattern of distribution in the water column because the trawling happens close to the substrate. Therefore, those fish that inhabit rocky or pelagic areas are not considered vulnerable to trawling (Jennings et al., 2001). Benthic or demersal species suffer habitat damage due to the impacts caused by bottom trawls. Essential habitat loss for given species may cause population decline (and, in some cases, extinction) (McCaughran, 1992).

Many bycatch species have no economic value and are discarded in the sea. Survival rate of these individuals is questionable because of the physiological effects that decompression causes when they are removed from great depths and brought rapidly to the surface (Nguyen, 2009). Species with the highest resistance to this practice belong to families Ariidae, Sciaenidae, and Haemulidae. The survival rate surpasses $33.3 \%$ in these three families. In addition, the low depth of the study area $(6 \mathrm{~m})$ is a positive factor for their survival 
Table 2. Bycatch species at the São Cristóvão beach, with the respective common names, families, percentage abundance (\%) and frequency (in months). Legend: * All common names were obtained from Fishbase; PA - Percentage Abundance; F Frequency.

\begin{tabular}{|c|c|c|c|c|}
\hline Family & Scientific name & Common name* & PA & $\mathrm{F}$ \\
\hline Haemulidae & Pomadasys corvinaeformis (Steindachner, 1868) & Roughneck grunt & 18.03 & 11 \\
\hline Ariidae & Cathorops spixii (Agassiz, 1829) & Madamango sea catfish & 15.64 & 11 \\
\hline Sciaenidae & Stellifer rastrifer (Jordan, 1889) & Rak estardrum & 15.35 & 8 \\
\hline Pristigasteridae & Pellona harroweri (Fowler, 1917) & American coastal pellona & 9.88 & 11 \\
\hline Sciaenidae & Stellifer stellifer (Bloch 1790) & Little croaker & 9.67 & 10 \\
\hline Pristigasteridae & Chirocentrodon bleekerianus (Poey, 1867) & Dogtooth herring & 7.41 & 8 \\
\hline Sciaenidae & Larimus breviceps Cuvier, 1830 & Shorthead drum & 6.21 & 12 \\
\hline Sciaenidae & Menticirrhus americanus (Linnaeus, 1758) & Southern kingcroaker & 3.06 & 12 \\
\hline Haemulidae & Conodon nobilis (Linnaeus, 1758) & Barred grunt & 2.00 & 12 \\
\hline Polynemidae & Polydactylus virginicus (Linnaeus, 1758) & Barbu & 1.38 & 12 \\
\hline Engraulidae & Anchoa spinifer (Valenciennes, 1848) & Spicule anchovy & 1.36 & 11 \\
\hline Carangidae & Selene setapinnis (Mitchill, 1815) & Atlantic moonfish & 1.23 & 11 \\
\hline Sciaenidae & Isopisthus parvipinnis (Cuvier, 1830) & Bigtooth corvina & 0.99 & 5 \\
\hline Engraulidae & Cetengraulis edentulus (Cuvier, 1829) & Atlantic anchoveta & 0.83 & 7 \\
\hline Engraulidae & Anchoa tricolor (Spix \& Agassiz, 1829) & Piquitinga anchovy & 0.81 & 4 \\
\hline Carangidae & Selene vomer (Linnaeus, 1758) & Lookdown & 0.63 & 10 \\
\hline Ariidae & Bagre marinus (Mitchill, 1815) & Gafftopsail sea catfish & 0.62 & 9 \\
\hline Trichiuridae & Trichiurus lepturus Linnaeus, 1758 & Largehead hairtail & 0.44 & 9 \\
\hline Diodontidae & Chilomycterus spinosus (Linnaeus, 1758) & Striped burrfish & 0.37 & 9 \\
\hline Sciaenidae & Stellifer brasiliensis (Schultz, 1945) & Cangoá & 0.36 & 4 \\
\hline Aphipiidae & Chaetodipterus faber (Broussonet, 1782) & Atlantic spadefish & 0.30 & 10 \\
\hline Paralichthydae & Citharichthys macrops Dresel, 1885 & Spotted whiff & 0.29 & 3 \\
\hline Cynoglossidae & Symphurus tessellatus (Quoy \& Gaimard, 1824) & Tongue fish & 0.26 & 10 \\
\hline Ariidae & Genidens barbus (Lacépède, 1803) & White sea catfish & 0.25 & 1 \\
\hline Ariidae & Bagre bagre (Linnaeus, 1766) & Coco sea catfish & 0.24 & 3 \\
\hline Sciaenidae & Bairdiella ronchus (Cuvier, 1830) & Ground croaker & 0.20 & 6 \\
\hline Carangidae & Chloroscombrus chrysurus (Linnaeus, 1766) & Atlantic bumper & 0.19 & 7 \\
\hline Gerreidae & Eucinostomus melanopterus (Bleeker, 1863) & Flagfin mojarra & 0.19 & 4 \\
\hline Pristigasteridae & Opisthonema oglinum (Lesueur, 1818) & Atlantic thread herring & 0.16 & 5 \\
\hline Triglidae & Prionotus punctatus (Bloch, 1793) & Bluewing searobin & 0.16 & 6 \\
\hline Dasyatidae & Dasyatis guttata (Bloch \& Schneider, 1801) & Long nosestingray & 0.13 & 4 \\
\hline Lutjanidae & Lutjanus synagris (Linnaeus, 1758) & Lane snapper & 0.13 & 4 \\
\hline Haemulidae & Genyatremus luteus (Bloch, 1790) & Torroto grunt & 0.12 & 4 \\
\hline Dactylopteridae & Dactylopterus volitans (Linnaeus, 1758) & Flying gurnard & 0.11 & 6 \\
\hline Paralichthydae & Citharichthys spilopterus Günther, 1862 & Bay whiff & 0.10 & 3 \\
\hline Tetraodontidae & Sphoeroides greeleyi Gilbert, 1900 & Green puffer & 0.10 & 5 \\
\hline Achiridae & Trinectes paulistanus (Miranda Ribeiro, 1915) & Slipper sole & 0.09 & 4 \\
\hline Gymnuridae & Gymnura micrura (Bloch \& Scheneider, 1801) & Smooth butterfly ray & 0.08 & 4 \\
\hline Sparidae & Archosargus probatocephalus (Walbaum, 1792) & Sheepshead & 0.08 & 3 \\
\hline Achiridae & Achirus declivis Chabanaud, 1940 & Plainfin sole & 0.07 & 2 \\
\hline Gerreidae & Diapterus rhombeus (Cuvier, 1829) & Caitipa mojarra & 0.07 & 2 \\
\hline Sciaenidae & Nebris microps Cuvier, 1830 & Smalley ecroaker & 0.07 & 3 \\
\hline Ariidae & Notarius grandicassis (Valenciennes, 1840) & Thomas seacatfish & 0.04 & 1 \\
\hline Engraulidae & Anchoa filifera (Fowler, 1915) & Long finger Anchovy & 0.04 & 1 \\
\hline Carangidae & Uraspis secunda (Poey, 1860) & Cottonmouth jack & 0.03 & 2 \\
\hline Sparidae & Archosargus rhomboidalis (Linnaeus, 1758) & The sea bream & 0.03 & 1 \\
\hline Cynoglossidae & Symphurus plagusia (Bloch \& Schneider, 1801) & Duskycheek tonguefish & 0.02 & 2 \\
\hline Sciaenidae & Paralonchurus brasiliensis (Steindachner, 1875) & Banded croaker & 0.02 & 2 \\
\hline Sphyraenidae & Sphyraena guachancho Cuvier, 1829 & Guachanche barracuda & 0.02 & 2 \\
\hline Synodontidae & Synodus intermedius (Spix \& Agassiz, 1829) & Sand diver & 0.02 & 1 \\
\hline Acanthuridae & Acanthurus chirurgus (Bloch, 1787) & Doctorfish & 0.01 & 1 \\
\hline Batrachoididae & Thalassophryne nattereri Steindachner, 1876 & Niquin & 0.01 & 1 \\
\hline Carangidae & Trachinotus falcatus (Linnaeus, 1758) & Permit & 0.01 & 1 \\
\hline Haemulidae & Haemulon aurolineatum Cuvier, 1830 & Tomtate grunt & 0.01 & 1 \\
\hline Mullidae & Pseudupeneus maculatus (Bloch, 1793) & Spotted goatfish & 0.01 & 1 \\
\hline Scombridae & Scomberomorus cavalla (Cuvier, 1829) & King mackerel & 0.01 & 1 \\
\hline Serranidae & Rypticus randalli Courtenay, 1967 & Plain soapfish & 0.01 & 1 \\
\hline Tetraodontidae & Sphoeroides testudineus (Linnaeus, 1758) & Checkered puffer & 0.01 & 1 \\
\hline
\end{tabular}

because they do not undergo decompression problems.

Bagre marinus, C. spixii, and P. corvinaeformis showed the highest correlation with survival. When individuals were dredged they reached the vessel still alive. However, despite their resistance to stress, B. marinus and C. spixii were most affected by trawling because their dependence to the substrate.

Regarding feeding habit, it was detected that the bycatch 
Table 3. Lengths of first capture and maturity, probabilities of caught below the length at maturity and breeding, mean and maximum length, and the mortality index of bycatch species at the São Cristóvão beach (RN). Legend: ** not found in the literature, size of sexual maturity. n - Number of individuals, L' - length at first capture, L(50) - length at first maturity, Prob. probability, Z - mortality index.

\begin{tabular}{|c|c|c|c|c|c|c|c|c|}
\hline Species & $\mathrm{n}$ & $\mathrm{L}^{\prime}(\mathrm{cm})$ & $\mathrm{L}(50)$ & $\begin{array}{l}\text { Pro. } L< \\
\text { L }(50)\end{array}$ & $\begin{array}{l}\text { Prob. of } \\
\text { breeding }\end{array}$ & Lmean \pm E.P. $(\mathrm{cm})$ & $\begin{array}{l}\text { Max. length }(\mathrm{cm}) \text { according to } \\
\text { references }\end{array}$ & Z \\
\hline Pomadasys corvinaeformis & 1604 & 4.2 & 15.8 & $p=0.476$ & $\mathrm{p}=0.524$ & $8.18 \pm 0.0376$ & 25 (Figueiredo \& Menezes, 1980) & 5.2 \\
\hline Cathorops spixii & 1391 & 7.7 & 12 & $p=0.149$ & $\mathrm{p}=0.851$ & $13.98 \pm 0.0822$ & 30 (Froese \& Pauly, 2008) & 3.6 \\
\hline Stellifer rastrifer & 1365 & 5.0 & 9.5 & $\mathrm{p}=0.385$ & $\mathrm{p}=0.615$ & $8.5 \pm 0.0329$ & 20 (Figueiredo \& Menezes, 1980) & 4.3 \\
\hline Pellona harroweri & 879 & 3.1 & 7 & $\mathrm{p}=0.382$ & $\mathrm{p}=0.618$ & $10 \pm 0.0592$ & 16 (Figueiredo \& Menezes ,1978) & 1.9 \\
\hline Stellifer stellifer & 860 & 4.6 & 7.5 & $p=0.012$ & $\mathrm{p}=0.988$ & $9.5 \pm 0.0393$ & 15 (Cervigón, 1993) & 2.1 \\
\hline Chirocentrodon bleekerianus & 659 & 4.9 & 7.6 & $p=0.056$ & $\mathrm{p}=0.944$ & $8.46 \pm 0.0453$ & 11.1 (Figueiredo \& Menezes, 1978) & 1.7 \\
\hline Larimus breviceps & 552 & 3.0 & 14 & $\mathrm{p}=0.312$ & $\mathrm{p}=0.688$ & $11.4 \pm 0.1393$ & 30 (Figueiredo \& Menezes, 1980) & 3.2 \\
\hline Menticirrhus americanus & 272 & 4.2 & 18.1 & $p=0.386$ & $p=0.614$ & $11.16 \pm 0.2269$ & 50 (Cervigón, 1993) & 6.6 \\
\hline Conodon nobilis & 178 & 5.6 & 16 & $p=0.375$ & $p=0.625$ & $8.96 \pm 0.1992$ & 33.6 (Cervigón et al., 1992) & 7.9 \\
\hline Polydactylus virginicus & 123 & 4.3 & ** & $\mathrm{p}=0.401$ & $\mathrm{p}=0.599$ & $10.9 \pm 0.2876$ & 32 (Motomura, 2004 ) & 4.2 \\
\hline Anchoa spinifer & 121 & 5.6 & ** & $\mathrm{p}=0.444$ & $\mathrm{p}=0.556$ & $12.4 \pm 0.2066$ & 24 (Figueiredo \& Menezes, 1978) & 2.7 \\
\hline Selene setapinnis & 109 & 3.6 & 20.5 & $\mathrm{p}=0.496$ & $\mathrm{p}=0.504$ & $7.88 \pm 0.2406$ & 40 (Figueiredo \& Menezes, 1980) & 8.5 \\
\hline Isopisthus parvipinnis & 88 & 5.3 & 15.9 & $\mathrm{p}=0.456$ & $\mathrm{p}=0.544$ & $10.4 \pm 0.6345$ & 25 (Figueiredo \& Menezes, 1980) & 3.9 \\
\hline Cetengraulis edentulus & 74 & 9.2 & 14,7 & $p=0.496$ & $\mathrm{p}=0.504$ & $11.3 \pm 0.1438$ & 16,6 (Froese \& Pauly, 2008) & 3.5 \\
\hline Anchoa tricolor & 71 & 7.8 & 7.6 & $p=0.312$ & $\mathrm{p}=0.688$ & $11.1 \pm 0.1170$ & 10 (Figueiredo \& Menezes, 1978) & 0.7 \\
\hline Selene vomer & 56 & 3.3 & 24.1 & $\mathrm{p}=0.452$ & $\mathrm{p}=0.548$ & $6.5 \pm 0.2449$ & 50 (Figueiredo \& Menezes, 1980) & 14.6 \\
\hline Bagre marinus & 55 & 8.0 & 33 & $\mathrm{p}=0.480$ & $\mathrm{p}=0.520$ & $11.4 \pm 0.3820$ & 69 (IGFA, 2001) & 17.9 \\
\hline
\end{tabular}

fishes feed mainly on benthic or demersal and benthopelagic organisms. They are thus more susceptible to dredging than pelagic species, as the preference for this kind of food directly influences their position in the water column (Wootton, 1989) and, consequently, their susceptibility to the gear used.

The criteria diet was a positive aspect for I. parvipinnis, S. vomer, S. setapinnis, and C. edentulus since they feed on benthic crustacean, but also small fishes, or zooplankton

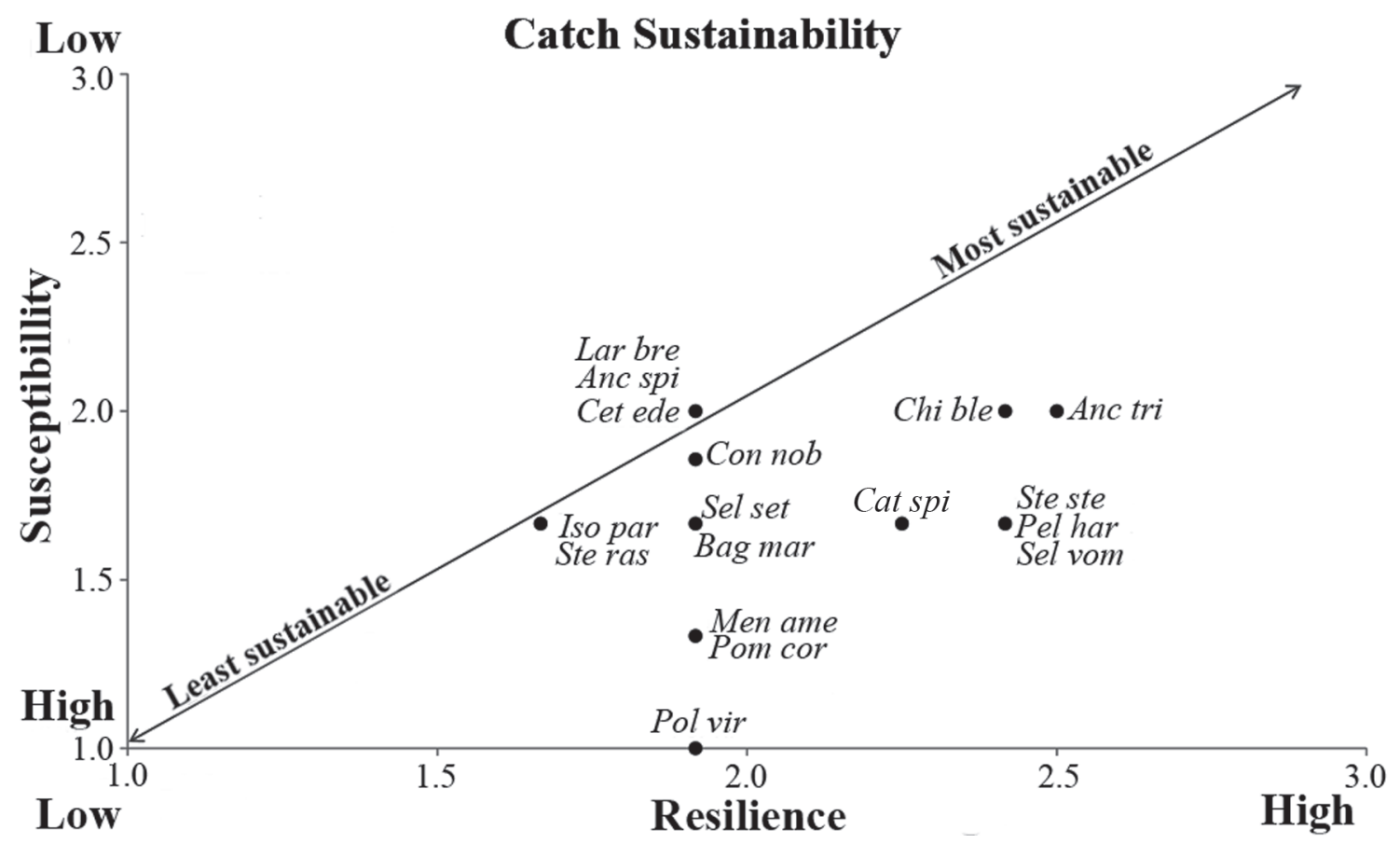

Fig. 2. Classification of bycatch species according to criteria indicating susceptibility to capture and resilience. The combination of these criteria provides a graphic that indicates the species with the most sustainable catch. Legend: Pom cor - Pomadasys corvinaeformis, Cat spi - Cathrops spixii, Ste ras - Stellifer rastrifer, Pel har - Pellona harroweri, Ste ste - Stellifer stellifer, Chi ble - Chirocentrodon bleekerianus, Lar bre - Larimus breviceps, Men ame - Menticirrhus americanus, Con nob Conodon nobilis, Pol vir - Polidactylus virginicus, Anc spi - Anchoa spinifer, Sel set - Selene setapinnis, Iso par - Isopisthus parvipinnis, Cet ede - Cetengraulius edentulus, Anc tri - Anchoa tricolor, Sel vom - Selene vomer, Bag mar - Bagre marinus. 


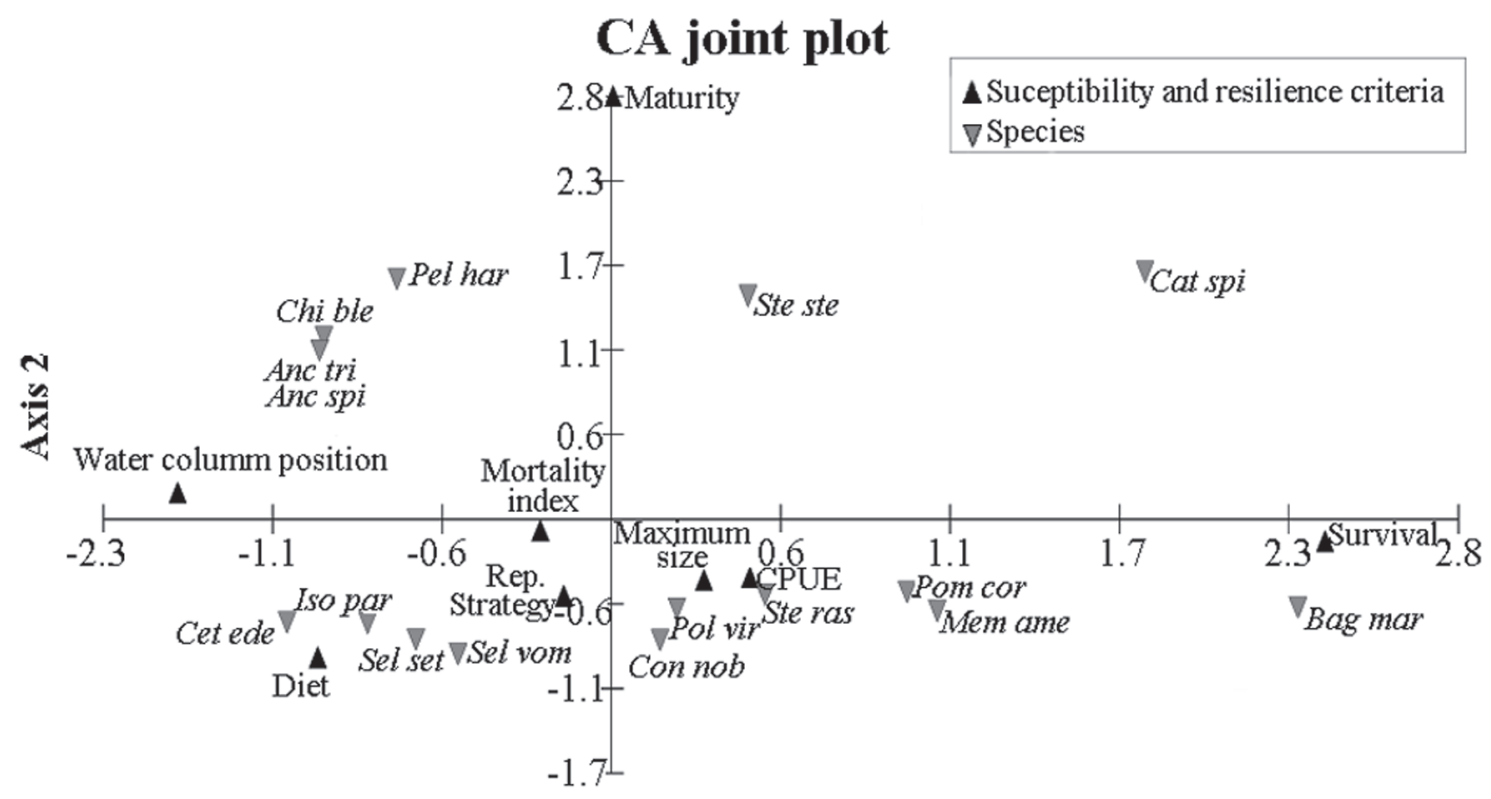

Axis 1

Fig. 3. Correspondence analysis showing the correlation among species and criteria used to evaluate the susceptibility and resilience. Legend: Pom cor - Pomadasys corvinaeformis, Cat spi - Cathrops spixii, Ste ras - Stellifer rastrifer, Pel har Pellona harroweri, Ste ste - Stellifer stellifer, Chi ble - Chirocentrodon bleekerianus, Lar bre - Larimus breviceps, Men ame - Menticirrhus americanus, Con nob - Conodon nobilis, Pol vir - Polidactylus virginicus, Anc spi - Anchoa spinifer, Sel set - Selene setapinnis, Iso par - Isopisthus parvipinnis, Cet ede - Cetengraulius edentulus, Anc tri - Anchoa tricolor, Sel vom Selene vomer, Bag mar - Bagre marinus, Rep - reproductive.

for the latter species (Carvalho-Filho, 1999). Conversely, S. stellifer and C. spixii was negatively related with this criterion, since their diet is composed mainly of polychaeta and crustacean (carcinofagous), but can feed on fishes, algae and mollusk (Menezes e Figueiredo, 1980; Le Bail et al., 2000), which live in sandy-muddy bottoms. Overall, position in the water column, survival and diet were fundamental criteria in classifying the different species, such as P. harroweri, L. breviceps and B. marinus.

Variations can be related to the way the trawls are maneuvered - although they operate on the bottom, pelagic species can be caught during hauling. Thus, this study recorded pelagic species that were captured as bycatch: A. spinifer, $A$. tricolor, C. bleekerianus, C. edentulus, and P. harroweri. Additionally, an overlap between the depth that trawling takes place and species' spatial distribution in the water column may influence susceptibility to capture. If the habitat presents unfavorable conditions, some pelagic species will try to find areas with better living conditions (Woottom, 1989). Since these are school-forming species, migration contributes to their vulnerability to the fishing gear (Jennings et al., 2001).

Species with late maturation are highly vulnerable to a possible risk of extinction (Roberts \& Hawkins, 1999; Jennings et al., 2001; Hutchings \& Reynolds, 2004). Due to the high capture rate of individuals that had spawned at least once, $P$. harroweri, $C$. bleekerianus, A. tricolor, S. stellifer, and C. spixii showed a positive relationship with maturity. Pomadasys corvinaeformis was negatively related to maturity, as most of the individuals captured were young. It was also verified that during the sampled period all of the abovementioned species - with the exception of P. corvinaeformis - had mean lengths greater than their size at maturity. In case of a population collapse this reproduction condition could improve the resilience process.

It is important to highlight that losses in life history parameters such as growth, fecundity and compensatory changes in survivorship help indicate the population's capacity to sustain (or not) a fishery. Issues like increases in the size at first maturity, decreases in the age at maturity and increases in fecundity correlated with increases in the size at maturity can be considered compensatory changes (Stearns \& Crandall, 1984).

Large-sized species can often be linked to factors related to vulnerability, such as late maturity and a high probability of being caught by trawls (Reynolds et al., 2005; Hutchings \& Reynolds, 2004). However, in this study maximum size did not have a strong influence on species' resilience because none of the species captured attain large sizes.

It is difficult for a fishery to attain equilibrium when the fishing effort was reduced in a short period after overexploitation (King, 2007). The population can decrease if the natural mortality rate, combined with fishing mortality, reduces the stock's levels and this continues even when fishing stops (Woottom, 1989). When the number of organisms caught is higher than the number produced, it can be said that the stock is being overfished (Fonteles-Filho, 1989). However Stellifer rastrifer 
and B. marinus presented extreme CPUE values (42.7 individuals/hour of trawling and 1.4 individuals/hour of trawling, respectively) and were not listed as least sustainable.

Among the species sampling in the present research, only B. marinus and C. spixii display demersal spawning and parental care (Fávaro et al., 2005). These reproductive strategies have a negative influence on populations' ability to recover, as egg development depends on oral incubation (Carvalho-Filho, 1999; Fávaro et al., 2005). Besides, all individuals of B. marinus were captured before reaching the size at first maturity; this might have happened because of this species' present late maturity (Pinheiro et al., 2006). The sum of these two parameters might have promoted this species' low resilience.

If a large number of individuals of reproductive age are fished, recruitment levels may fluctuate. In terms of recruitment, overfishing may occur when a stock is fished down to a level in which recruitment alone cannot replace the number of individuals lost (Jennings et al., 2001). In this case, it becomes extremely necessary to maintain a number of mature adults in a level that assures the population's continuity (King, 2007). Disequilibrium in recruitment may also result in an imbalance in age structure - it will increase the number of immature individuals in the fish stock, which will lead to a decrease in the size at sexual maturity (Fonteles-Filho, 1989). When the catchability of a given species remains high, there is a great probability that the size of the stock will decrease and the species will become at risk. This includes schooling and aggregating species, which are highly vulnerable even when stock abundance remains low (King, 2007).

When fishing mortality rates decrease after a collapse, it is expected that the population recover faster (Hutchings \& Reynolds, 2004). An experiment conducted by Hutchings (2000) proved that populations which underwent a decrease in fishing mortality had their stock restored to $39 \%$ of the original size when compared to populations that remained constant or which mortality rate increased; in the last case only $29 \%$ of the original size was recovered. Thus, the mortality due to fishing might have to be reduced for a given population to recover.

Bagre marinus and A. tricolor had the highest and lowest mortality index values (17.9 and 0.7 , respectively) among the species analyzed. High mortality rates are recorded when there is a considerable difference between the length of the fish caught and the maximum size according to the literature (Sparre \& Venema, 1997). Fishing generally imposes a mortality rate that is strongly size selective, which can result in some phenotypic changes (such as alterations in reproductive parameters) as fish respond to the new environmental conditions (King, 2007; Nelson \& Soulé, 1987). Normally, commercial trawling is performed in deeper areas, over $10 \mathrm{~m}$ (Somers, 1994), and more distant from the coast. However, in São Cristóvão Beach trawling is practiced in shallow waters and very close to coast.

Prawn trawling is clearly anthropogenic. The incidental capture of non-target species has been conducted unsustainably, as most of the organisms are caught before reaching their size at first maturity. Such a removal of species from the ecosystem can cause biodiversity losses and the local extinction of some species. Non-target species that are caught incidentally by fishing gear can be classified as vulnerable. Even at very low abundances, these species will continue to be caught, because the fishing gear is not selective. As a result of the fishery's multi-specific nature, it is difficult to implement mitigation measures for specific species. In this case it is suggest the creation of fishing exclusion zones with the purpose of promoting species' natural recovery without the interference of mortality caused by fishing.

\section{Acknowledgments}

We would like to thank José Luis Novaes for helpful comments on the first draft of the paper.

\section{Literature Cited}

Alverson, D. L., M. H. Freeber, S. A. Murawski \& J. G. Pope. 1994. A global assessment of fisheries bycatch and discards. FAO Fisheries Technical Paper 339. Rome, FAO, 233p.

Branco, J. O. 1999. Biologia do Xiphopenaeus kroyeri (Heller, 1862) (Decapoda: Penaeidae), análise da fauna acompanhante e das aves marinhas relacionadas à sua pesca, na região de Penha, SC, Brasil. Unpublished MSc. Thesis. Universidade de São Carlos, São Paulo, 146p.

Branco, J. O. 2005. Biologia e Pesca do Camarão Sete-Barbas Xiphopenaeus kroyeri (Heller) (Crustacea: Penaeidae) na Armação do Itapocoroy, Penha SC. Brasil. Revista Brasileira de Zoologia, 22: 1050-1062.

Branco, J. O. \& J. R. Verani. 2006. Pesca do camarão sete-barbas e sua fauna acompanhante, na Armação do Itapocoray, Penha, SC. Pp. 153-170. In: J. O. Branco \& A. W. C. Marenzi (Eds). Bases ecológicas para um desenvolvimento sustentável: estudos de caso em Penha, SC. Itajaí, UNIVALI, 292p.

Carvalho Filho, A. 1999. Peixes da costa brasileira. $3^{\text {rd. }}$ Ed. São Paulo, Editora Melro, 283p.

Cervigón, F. R. 1993. Los peces marinos de Venezuela. Caracas, Fundación Científica Los Roques, 295p.

Cervigón, F. R., W. Cipriani, L. Fischer, M. Garibaldi, A. J. Hendrickx, R. Lemus, J. M. Márquez, G. Poutiers, B. Robaina \& Rodriguez. 1992. Fichas FAO de identificación de especies para los fines de la pesca. Guía de campo de las especies comerciales marinas y de aquas salobres de la costa septentrional de Sur América. Roma, FAO, 513p.

Clucas, I. 1997. A study of the options for utilization of bycatch and discards from marine capture fisheries. FAO Fisheries Circular, 928. Rome, FAO, 59p.

Coelho, J. A. P., A. Puzzi, R. Graça-Lopes, E. S. Rodrigues \& O. Prieto-Jr. 1986. Análise da rejeição de peixes na pesca artesanal dirigida ao camarão sete-barbas (Xiphopenaeus kroyeri) no litoral do estado de São Paulo. Boletim do Instituto de Pesca, 13: 51-61.

Fávaro, L. F., F. A. Frehse, R. N. Oliveira \& R. Schawrz-Júnior. 2005. Reprodução do bagre amarelo, Cathorops spixii (Agassiz) (Siluriformes: Ariidae), da Baía de Pinheiros, região estuarina do litoral do Paraná, Brasil. Revista Brasileira de Zoologia, 22: 1022-1029.

Feitosa, C. V., B. P. Ferreira \& M. E. Araújo. 2008. A rapid new method for assessing sustainability of ornamental fish by-catch 
from coral reefs. Marine and Freshwater Research, 59: 10921100.

Figueiredo, J. L. \& N. A. Menezes. 1978. Manual de Peixes Marinhos do Sudeste do Brasil. II. Teleostei (1). São Paulo, Museu de Zoologia da Universidade de São Paulo, 110p.

Figueiredo, J.L. \& N. A. Menezes. 1980. Manual de Peixes Marinhos do Sudeste do Brasil: III. Teleostei (2). São Paulo, Museu de Zoologia da Universidade de São Paulo, 90p.

Figueiredo, J.L. \& N.A. Menezes. 2000. Manual de Peixes Marinhos do Sudeste do Brasil: VI Teleostei (5). São Paulo, Museu de Zoologia da Universidade de São Paulo, 116p.

Fonteles-Filho, A. A. 1989. Recursos pesqueiros: biologia e dinâmica populacional. Fortaleza, Imprensa Oficial do Ceará, 296p.

Froese, R. \& D. Pauly. 2011. FishBase. World Wide Web electronic publication. Available from: http://www.fishbase.org/ (Accessed 31 May 2011).

Garcia Júnior, J. 2006. Inventário das espécies de peixes da costa do estado do Rio Grande do Norte e aspectos zoogeográficos da ictiofauna recifal do oceano atlântico. Unpublished MSc. Thesis. Universidade Federal do Rio Grande do Norte, Natal, 125p.

Hill, B. J. \& T. J. Wassenberg. 1990. Fate discards from prawn trawlers in Torres Strait. Australian Journal of Marine and Freshwater Research, 41: 53-61.

Hutchings, J. A. 2000. Collapse and recovery of marine fishes. Nature, 406: 882-885.

Hutchings, J. A. \& J. D. Reynolds. 2004. Marine fish population collapses: consequences for recovery an extinction risk. BioScience, 4: 297-309.

International Game Fish Association. 2001. IGFA. Database of all records recorded by IGFA until August. Made available to FishBase. IGFA, Fort Lauderdale, USA. Available from: http:/ /www.igfa.org/. (Accessed 31 May 2011).

Instituto de Desenvolvimento Econômico e Meio Ambiente. (IDEMA). 2002. Perfil do Estado do Rio Grande do Norte. Natal, Secretaria de Estado do Planejamento e das Finanças do Rio Grande do Norte, $85 \mathrm{p}$.

Instituto de Desenvolvimento Econômico e Meio Ambiente. (IDEMA). 2003. Relatório final dos estudos para implementação da ZEE dos estuários do Rio Grande do Norte e seus entornos. Natal, Subcoordenadora de Gerenciamento Costeiro, 190p.

Isaac, V., A. S. Martins, M. Haimovici, J. P. Castello \& J. M. Andriguetto. 2006. Síntese do estado de conhecimento sobre a pesca marinha e estuarina do Brasil. Pp.181-186. In: Isaac, V. J., A. G. Martins, M. Haimovici \& J. M. Andriguetto (Eds.). A pesca marinha e estuarina no início do século XXI: recursos, tecnologias, aspectos socioeconômicos e institucionais. $1^{\text {th }} \mathrm{Ed}$. Belém, Universidade Federal do Pará, 188p.

Jennings, S., M. J. Kaiser \& J. D. Reynolds. 2001. Marine Fisheries ecology. $6^{\text {th }}$ Ed. Oxford, Blackwell Science, 432p.

King, M. 2007. Fisheries biology, assessment and management. $2^{\text {nd }}$ Ed. Oxford, Blackwell Publishing, 382p.

Kinieb, R. T. 1991. Indirect effects in experimental studies of marine soft sediment communities. American Zoologist, 31: 874-885.

Klippel, S., C. M. Vooren, A. F. Lamónaca \& M. B. Peres. 2005. A pesca industrial no sul do Brasil. Pp. 135-178. In: Vooren, C. M. \& S. Klippel (Eds.). Ações para a conservação de tubarões e raias no sul do Brasil. Porto Alegre, Igaré, 261p.

Le Bail, P. Y., P. Keith \& P. Planquette. 2000. Atlas des poissons d'eau douce de Guyane. Tome 2, Fascicule II: Siluriformes. Paris: Publications scientifiques du Muséum national d'Histoire naturelle, $307 \mathrm{p}$.
McCaughran, D. A. 1992. Standardized nomenclature and methods of defining bycatch levels and implications. Pp. 200-201. In: Schoning, R. W., R. W. Jacobson (Eds.). Proceedings of the national industry bycatch Workshop. Natural resource consultants. Seattle, Washington.

Menezes, N. A. \& J. L. Figueiredo. 1980. Manual de Peixes Marinhos do Sudeste do Brasil: IV. Teleostei (3). São Paulo, Museu de Zoologia da Universidade de São Paulo, 96p.

Menezes, N. A. \& J. L. Figueiredo. 1985. Manual de Peixes Marinhos do Sudeste do Brasil: IV. Teleostei (4). São Paulo, Museu de Zoologia da Universidade de São Paulo, 105p.

Motomura, H. 2004. Threadfins of the world (Family Polynemidae): An annotated and illustrated catalogue of polynemid species known to date. Pp. 77-78. In: H. Motomura (Eds.) FAO Species Catalogue for Fishery Purposes, 3. Rome, FAO, 117p.

Nelson, K. \& M. Soulé. 1987. Genetical conservation of exploited fishes. Pp. 345-368. In: Ryman, N. \& F. Utter (Eds.). Population Genetics and Fishery Management. Seattle, University of Washington, 488p.

Nguyen, V., M. A. Gravel, A. Mapleston, K. C. Hanson \& S. J. Cooke. 2009. The post- release behavior and fate of tournamentcaught smallmouth bass after 'fizzing' to alleviate distended swim bladders. Fisheries Research, 96: 313-318.

Nikolskii, G. V. 1969. Theory of fish population dynamics as the biological background for rational exploitation and management of fishery resources. Translated from the Russian edition (Moscow, 1965) by J. E. S. Bradley. R. Jones, Oliver and Boyd (Eds.). Edinburgh, 324p.

Pilskaln, C. H., J. H. Churchill \& L. M. Mayer. 1998. Resuspension of sediments by bottom trawling in the Gulf of Maine and potential geochemical consequences. Conservation Biology, 12: 1223-1224.

Pina, J. V. \& P. T. Chaves. 2009. Incidência da pesca de arrasto camaroeiro sobre peixes em atividade reprodutiva: uma avaliação no litoral norte de Santa Catarina, Brasil. Atlântica, 31: 99-106.

Pinheiro, P., M. K. Broadhurst, F. H. V. Hazin, T. Bezerra \& S. Hamilton. 2006. Reproduction in Bagre marinus (Ariidae) off Pernambuco, northeastern Brazil. Journal of Applied ichthyology, 22: 189-192

Reynolds, J. D., N. K. Dulvy, N. B. Goodwin \& J. A. Hutchings. 2005. Biology of extinction risk in marine fishes. Proceedings of The Royal Society, 227: 2337-2344.

Riemann, B. \& E. Hoffman. 1991. Ecological consequences of dredging and bottom trawling in the Limfjord, Denmark. Marine Ecology Progress Series, 69: 171-178.

Roberts, C. M. \& J. P. Hawkins. 1999. Extinction risk in the sea. Trends in Ecology and Evolution, 14: 241-246.

Somers, I. 1994. No resources, no fishery, prawns and their habitat. Pp. 49-65. In: P. C. Pownall (Ed.). Australia's Northern Prawn Fishery: The First 25 Years. Cleveland, Queensland, 179p.

Sparre, P. \& S. C. Venema. 1997. Introdução à avaliação de mananciais de peixes tropicais. FAO, Rome, 404p.

Stearns, S. C. \& R. E. Crandall. 1984. Plasticity for age and size at sexual maturity: a life-history response to unavoidable stress. Pp. 13-33. In: G. W. Potts \& R. J. Wootton (Eds.). Fish Reproduction: Strategies and Tactics. Lodon, Academic Press, 424p.

Stobutzki, I., M. Miller \& D. Brewer. 2001. Sustainability of fishery bycatch: a process for assessing highly diverse and numerous bycatch. Environmental Conservation, 28: 167-181.

Tischer, M. \& M. C. F. Santos. 2001. Algumas considerações sobre a ictiofauna acompanhante da pesca de camarões na foz do rio São Francisco (Alagoas/Sergipe - Brasil). Boletim Técnico-Científico do CEPENE, 9: 155-165. 
Tomáz, A. R. G., M. L. Gasalla \& M. H. Carneiro. 2003. Dinâmica da frota do arrasto de portas do estado de São Paulo. Pp. 39-63. In: Cergole, M. C. \& C. L. B. R. Wongtschowski (Eds.). Dinâmica das frotas pesqueiras - análise das principais pescarias comerciais do sudeste sul do Brasil. São Paulo, Evoluir, 376p.

Vianna, M. \& T. Almeida. 2005. Bony fish bycatch in the southern Brazil pink shrimp (Farfantepenaeus brasiliensis and $F$. paulensis) fishery. Brazilian Archives of Biology and Technology, 48: 611-623.

Wassenberg, T. J. \& B. J. Hill. 1989. The effect of trawling and subsequent handling on the survival rates of the bycatch of prawn trawlers in Morcton Bay, Australia. Fisheries Research, 7: 99-110.

Wootton, R. J. 1989. Feeding. In: Wootton, R. J. (Ed.). Ecology of Teleost Fishes. $2^{\text {nd }}$ Ed. Dordrecht, Kluwer Academic Publishers, 392 p.

Submitted March 23, 2012

Accepted September 8, 2012 by Francisco Gerson Araujo Published March 31, 2013 